\title{
Influence of priming concentration on the growth and yield of amaranth (Amaranthus cruentus L.) in Sokoto semi-arid zone of Nigeria
}

\author{
Mukhtar Musa*, Aminu Aliyu Lawal \\ Department of Crop Science, Usmanu Danfodiyo University, Sokoto, Sokoto State, Nigeria \\ Email address: \\ mukhtar.musa@udusok.edu.ng (M. Musa)
}

\section{To cite this article:}

Mukhtar Musa, Aminu Aliyu Lawal. Influence of Priming Concentration on the Growth and Yield of Amaranth (Amaranthus cruentus L.) in Sokoto Semi-Arid Zone of Nigeria. Journal of Plant Sciences. Vol. 3, No. 1, 2015, pp. 27-30.

doi: $10.11648 /$ j.jps.20150301.15

\begin{abstract}
Two field trials were conducted during the 2012 cropping season at the Fruits and Vegetable Teaching and Research Farm of the Department of Crop Science, Usmanu Danfodiyo University Sokoto, to evaluate the effect of priming concentration on the growth and yield of Amaranth. Treatments consisted of four priming concentrations $\left(0 \%, 0.5 \%, 1 \%\right.$ and $\left.2 \% \mathrm{KNO}_{3}\right)$. The treatments were laid out in a completely randomized design(CRD) replicated three times for the germination test and randomized complete block design (RCBD) for the field trial. Data were collected on days to $50 \%$ germination, percentage germination, days to $50 \%$ emergence, percentage emergence and fresh weight. Results showed significant effect of priming concentration on days to $50 \%$ germination, percentage emergence and days to $50 \%$ emergence. Soaking seeds in $0.5 \% \mathrm{KNO}_{3}$ reduced the number of days to $50 \%$ germination and emergence and also recorded higher percentage germination. Thus, it could be concluded that amaranth seeds should be primed with $0.5 \% \mathrm{KNO}_{3}$ solution for faster and higher seed germination of the crop.
\end{abstract}

Keywords: Amaranth, Growth and Yield, Priming Concentration, Semi-Arid Zone

\section{Introduction}

Amaranth (Amaranthus cruentus) is an excellent leaf vegetable grown throughout the tropics. The leaves (edible part) represent $76 \%$ of the total fresh weight of shoots and one hundred grams contain $84 \mathrm{~g}$ water, $4.6 \mathrm{~g}$ protein, $1.8 \mathrm{~g}$ cellulose, $410 \mathrm{mg}$ calcium, $8.9 \mathrm{mg}$ iron, $5.7 \mathrm{mg}$ beta-carotene and $64 \mathrm{mg}$ vitamin $\mathrm{C}$. The leaves are also rich in vitamin $\mathrm{A}$ and potassium and represent the largest source of nutrients among all the vegetables that could be grown in tropical Africa $[1,2]$.

Despite the role of amaranths as one of the sources of vitamins A, B, thiamine, niacin, riboflavin, and some other dietary minerals such as calcium, iron, potassium, zinc, copper, and manganese which are comparable to common grains such as wheat, oats, and others [1], its production in Nigeria remains low when compared to other countries [2]. There is therefore, the need to improve its production to meet the demand of the consumers. Seed priming before planting is reported to enhance the germination and seedlings growth by controlling moisture imbibition and minimizing the vagaries of the adverse effects of weather and soil conditions [3]. The effect of priming has been attributed to metabolic repair and activation of seed during water imbibition $[4,5]$. Priming methods differ depending on crop species and seed germination condition. Several studies on seed germination and seed emergence showed the beneficial effect of seed priming using different methods [6-8]. Pre-sowing seed treatment is a low risk technique that is being used to increase crop establishment under unfavorable conditions [2]. Paul and Choudhury [9] observed that seed soaked in 0.5 to $1 \%$ solutions of $\mathrm{KCl}$ or $\mathrm{K}_{2} \mathrm{SO}_{4}$ significantly increased plant height and yield attributes in wheat. Moosavi et al. [10] reported that osmopriming and hydro-priming of amaranth seeds significantly increased germination percentage, speed of germination and seedling vigour in all cultivars. Recently, Musa et al. [2] reported soaking amaranths seed for two hours as best for improving germination and emergence performance of the crop. Thus, this experiment was conducted to study the influence of seed priming concentration on the growth and yield of amaranth in semi-arid environment. 


\section{Materials and Methods}

For both germination and emergence tests, treatments consisted of four priming concentrations $(0 \%, 0.5 \%, 1 \%$ and $2 \% \mathrm{KNO}_{3}$ ) laid out in a completely randomized design (CRD) replicated three times.

Seed Priming: Seed priming was carried out in the Crop Science Laboratory, Usmanu Danfodiyo University, Sokoto. Seeds of the amaranth cultivar were sourced from Sokoto Agricultural Development Programme in Sokoto, Nigeria. The seeds were primed (soaked) in $\mathrm{KNO}_{3}$ solution containing $0 \%, 0.5 \%, 1 \%$ and $2 \% \mathrm{KNO}_{3}$ salt. All the seeds for the various treatments were soaked for a period of 2 hours as suggested by Musa et al. [2]. $50 \mathrm{~g}$ of the amaranth seeds each were soaked in $500 \mathrm{ml}$ containing the various priming concentrations. After priming, seeds were air-dried back to their initial moisture content. At the time of experiment, the temperature of the $\mathrm{KNO}_{3}$ solution and the distilled water used as control $(0 \%)$ during the priming was $28^{\circ} \mathrm{C}$ and $29^{\circ} \mathrm{C}$ during the first and second trials respectively. The temperature of the surrounding environment was $29^{\circ} \mathrm{C}$ and $30^{\circ} \mathrm{C}$ respectively.

Germination Test: For both trials, 30 seeds were placed on moist filter paper of $90 \mathrm{~mm}$ in diameter in petri dishes for each treatment and replicated three times. Droplets of water were applied everyday on the filter paper to provide adequate moisture for seed germination. Seed was considered germinated when the radicle emerged through the seed coat. Germination count was taken daily for 14 days. Germination percentage was computed using the following:

$$
\text { Germination percentage }=\frac{\text { Total seeds germinated }}{\text { Total seeds sown }} X 100
$$

Field emergence: The emergence test was carried out in 2012 cropping season at the Fruits and Vegetable Teaching and Research Farm of Usmanu Danfodiyo University, Sokoto. Sokoto is located on latitude $14^{0} \mathrm{~N}-15^{0} \mathrm{~N}$ and longitude $4^{0}-5^{0} \mathrm{E}$ [11]. Annual rainfall ranges from $380 \mathrm{~mm}$ to $763 \mathrm{~mm}$. The seeds were sown through drilling method with a row to row spacing of $20 \mathrm{~cm}$ at a depth of $0.5-1 \mathrm{~cm}$. Gross plot size was $2 \mathrm{~m} \times 2 \mathrm{~m}\left(4 \mathrm{~m}^{2}\right)$ and the net plot was $1.6 \mathrm{~m} \times 1.6 \mathrm{~m}\left(2.56 \mathrm{~m}^{2}\right)$. Emergence test involved counting the number of plants that emerged on the soil surface daily. It was computed using the following:

$$
\text { Emergence percentage }=\frac{\text { Number of seedlings emerged }}{\text { Number of seeds sown }} \times 100
$$

Data were collected on days to $50 \%$ germination, percentage germination, days to $50 \%$ emergence, percentage emergence and fresh weight. The data collected were subjected to analysis of variance (ANOVA) procedure for completely randomized design (CRD) and randomized complete block design (RCBD) for the laboratory and field experiments respectively, using $\mathrm{SAS} \AA$ computer package. Means showing significant differences were separated using Duncan's Multiple Range Test (DMRT).

\section{Results}

\subsection{Days to 50\% Germination}

Days to $50 \%$ germination of amaranth as influenced by priming concentration during the first trial, second trial and the mean performance is presented in Table 1.

Significant $(p<0.05)$ effect of priming concentration on days to $50 \%$ germination was observed during the second trial. Using $\mathrm{KNO}_{3}$ salt concentration of $0.5,1.0$ and $2.0 \%$ reduced the number of days to $50 \%$ germination from 3.2 days recorded where $\mathrm{KNO}_{3}$ was not used in the priming media to $2.1-2.2$ days which was similar between the concentration levels (Table 1). But, for the first trial and the mean performance, the number of days to $50 \%$ germination which ranged from 1.8-2.1 days and 2.0-2.6 days respectively, were not influenced by priming concentration.

Table 1. Days to 50\% germination of amaranths as influenced by priming concentration during the 2012 cropping season.

\begin{tabular}{llll}
\hline Treatments & First trial & Second trial & Combined \\
\hline Concentration $(\%)$ & & & \\
0 & 1.9 & $3.2^{\mathrm{a}}$ & 2.6 \\
0.5 & 2.1 & $2.2^{\mathrm{b}}$ & 2.1 \\
1 & 2.1 & $2.1^{\mathrm{b}}$ & 2.1 \\
2 & 1.8 & $2.1^{\mathrm{b}}$ & 2.0 \\
$\mathrm{SE}( \pm)$ & 0.13 & 029 & 0.17 \\
Significance & $\mathrm{ns}$ & $*$ & $\mathrm{~ns}$ \\
\hline
\end{tabular}

Means in a column followed by same letter(s) in a superscript within a treatment group are not significantly different using DMRT at 5\% level; ns $=$ not significant,$*=$ significant

\subsection{Percentage Germination}

Percentage germination of amaranths as influenced by priming concentration during the first trial, second trial and the combined mean performance is presented in Table 2.

Significant $(p<0.05)$ effect of priming concentration on the percentage germination of amaranth was observed during the second trial and the mean performance. Higher percentage germination was recorded in the treatments primed with $\mathrm{KNO}_{3}$ salt during the second trial (86.3-88.8\%) and the mean performance $(81.2-85.6 \%)$ than the treatments soaked in water only which recorded 68.7 and $70.9 \%$ during the second trial and mean performance respectively. But, the difference in percentage germination among the $\mathrm{KNO}_{3}$ salt concentrations $(0.5,1.0$ and $2.0 \%)$ was not observed (Table 2$)$.

Table 2. Percentage germination of amaranths as influenced by priming concentration during the 2012 cropping season.

\begin{tabular}{llll}
\hline Treatments & First trial & Second trial & Combined \\
\hline Concentration $(\%)$ & & & \\
0 & 73.1 & $68.7^{\mathrm{b}}$ & $70.9^{\mathrm{b}}$ \\
0.5 & 76.17 & $86.3^{\mathrm{a}}$ & $81.2^{\mathrm{a}}$ \\
1 & 79.0 & $88.0^{\mathrm{a}}$ & $83.0^{\mathrm{a}}$ \\
2 & 82.4 & $88.8^{\mathrm{a}}$ & $85.6^{\mathrm{a}}$ \\
SE $( \pm)$ & 3.35 & 2.18 & 1.76 \\
Significance & $\mathrm{ns}$ & $*$ & $*$ \\
\hline
\end{tabular}

Means in a column followed by same letter(s) in a superscript within a treatment group are not significantly different using DMRT at 5\% level; ns $=$ not significant, $*=$ significant 


\subsection{Days to $50 \%$ Emergence}

Days to $50 \%$ emergence of amaranths as influenced by priming concentration during the first trial, second trial and the combined is presented in Table 3 .

Significant $(\mathrm{p}<0.05)$ effect of priming concentration on days to $50 \%$ emergence of amaranth was observed during the first trial and the combined (Table 3). Days to $50 \%$ emergence of the crop was observed in lesser number of days in treatments soaked with $0 \%$ and $0.5 \% \mathrm{KNO}_{3}$ during the first trial (2.3-3.1 days) and the combined (2.8-3.0 days) than the treatments soaked in $1.0 \%$ and $2.0 \% \mathrm{KNO}_{3}$ solution which recorded 4.4-5.8 days in the first trial and 3.5-4.5 days in the combined. However, for the second trial the days to $50 \%$ emergence of the crop which ranged from 2.7-3.3 days was not influenced by priming concentration.

Table 3. Days to 50\% emergence of amaranths as influenced by priming concentration during the 2012 cropping season.

\begin{tabular}{llll}
\hline Treatments & First trial & Second trial & Combined \\
\hline Concentration $(\%)$ & & & \\
0 & $3.1^{\mathrm{c}}$ & 3.0 & $3.0^{\mathrm{b}}$ \\
0.5 & $2.3^{\mathrm{c}}$ & 3.3 & $2.8^{\mathrm{b}}$ \\
1.0 & $5.8^{\mathrm{a}}$ & 3.2 & $4.5^{\mathrm{a}}$ \\
2 & $4.4^{\mathrm{b}}$ & 2.7 & $3.5^{\mathrm{a}}$ \\
$\mathrm{SE}( \pm)$ & 0.39 & 042 & 0.39 \\
Significance & $*$ & $\mathrm{~ns}$ & $*$ \\
\hline
\end{tabular}

Means in a column followed by same letter(s) in a superscript within a treatment group are not significantly different using DMRT at 5\% level; ns $=$ not significant, $*=$ significant

\subsection{Percentage Seedling Emergence}

The percentage seeding emergence of the crop which ranged from $54.2-78.0 \%, 56.1-73.6 \%$ and $63.5-67.1 \%$ during the first trial, second trial and the combined respectively, was not significantly $(\mathrm{p}>0.05)$ influenced by priming concentration (Table 4).

Table 4. Percentage emergence of amaranths as influenced by priming concentration during the 2012 cropping season.

\begin{tabular}{llll}
\hline Treatments & First trial & Second trial & Combined \\
\hline Concentration $(\%)$ & & & \\
0 & 78.0 & 56.1 & 67.1 \\
0.5 & 65.7 & 62.5 & 64.1 \\
1 & 69.3 & 63.6 & 66.5 \\
2 & 54.2 & 73.6 & 63.5 \\
SE $( \pm)$ & 5.99 & 6.10 & 4.30 \\
Significance & $\mathrm{ns}$ & $\mathrm{ns}$ & $\mathrm{ns}$ \\
\hline
\end{tabular}

Means in a column followed by same letter(s) in a superscript within a treatment group are not significantly different using DMRT at 5\% level; ns $=$ not significant, ${ }^{*}=$ significant

\subsection{Fresh Weight}

The fresh weight of the crop which ranged from 10.3$12.5 \mathrm{~g}, 12.8-13.5 \mathrm{~g}$ and $11.7-12.6 \mathrm{~g}$ during the first trial, second trial and the mean performance of the two trials combined was not significantly $(p>0.05)$ influenced by the various priming concentrations (Table 5).
Table 5. Fresh weight (g/plant) of amaranths as influenced by priming concentration during the 2012 cropping season.

\begin{tabular}{llll}
\hline Treatments & First trial & Second trial & Combined \\
\hline Concentration $(\%)$ & & & \\
0 & 11.3 & 13.0 & 12.2 \\
0.5 & 11.1 & 13.5 & 12.3 \\
1 & 12.5 & 12.8 & 12.6 \\
2 & 10.3 & 12.8 & 11.7 \\
SE $( \pm)$ & 0.67 & 1.42 & 0.78 \\
Significance & $\mathrm{ns}$ & $\mathrm{ns}$ & $\mathrm{ns}$ \\
\hline
\end{tabular}

Means in a column followed by same letter(s) in a superscript within a treatment group are not significantly different using DMRT at 5\% level; $\mathrm{ns}=$ not significant, $*=$ significant

\section{Discussion}

The finding of this research showed the benefit of seed priming using $\mathrm{KNO}_{3}$ salt solution as priming media in improving the performance of amaranth in the semi-arid environment where good crop establishment seldom occurs. The remarkable performance of the crop observed from using $\mathrm{KNO}_{3}$ salt shows that the salt could be used to improve crop establishment in this environment characterized by unfavorable conditions for seedling establishment. This view on improving crop establishment was reported earlier by many researchers $[2,6-8]$.

The attainment of $50 \%$ germination in lesser number of days in the second trial in seeds primed with $\mathrm{KNO}_{3}$ salt of $0.5-2.0 \%$ (2.1-2.2 days) compared to using distilled water alone which recorded 3.2 days shows the beneficial effect of using the salt as priming media and $0.5 \%$ was the best concentration that could be used to prime the crop. The finding here could be attributed to the effect of seed priming on the early stages of germination process which causes completion of pre-germination metabolic activities in the seed and makes the seed ready for radicle protrusion once it re-imbibed moisture on the field. This agrees with the findings of Szabolcs, [12] and Sivritepe et al. [13] who reported that earlier and more uniform germination are probably due to stimulatory effects of priming on the early stages of the germination process.

The increase in percentage germination of amaranth recorded in the treatments where $\mathrm{KNO}_{3}$ salt was used compared to using water alone could be attributed to the role of seed priming using $\mathrm{KNO}_{3}$ salt in seeds repair and removal of germination inhibiting substances commonly found in the seeds of most vegetables plants. This agrees with the findings of Jie et al. [14] who reported that osmo-priming activates the processes of germination through affecting the oxidative metabolism. Also, use of $\mathrm{KNO}_{3}$ salt might have supplied $\mathrm{NO}_{3}$ to the seed and caused exo-osmosis that resulted in the removal of germination-inhibiting substances. Seed osmopriming is reported to increase the seed germination potential, resulting in increased stress tolerance of germinating seeds [15]. This is in line with the findings of McDonald [3] who reported that priming may improve germination by accelerating imbibition which in turn would facilitate the radicle protrusion and seed germination. 
The reduction in days to $50 \%$ emergence of amaranth obtained in the treatments soaked in 0 and $0.5 \% \mathrm{KNO}_{3}$ solution compared to using higher concentrations suggested that faster seedling emergence could be reached without $\mathrm{KNO}_{3}$ salt concentration and where used to enhance germination as observed above in days to $50 \%$ germination and percentage germination, it should not exceed $0.5 \%$. The finding here was contrary to that of Singh et al. [16], who observed better seedling performance with osmo-primed seeds in cowpea. The reason could be because of the differences in the crop under investigation and Amaranth is quite a small seed plant compared to cowpea.

\section{Conclusion}

The finding of this research showed the benefit of using $\mathrm{KNO}_{3}$ as a priming media in improving germination characteristics of amaranth in the semi-arid tropics. The highest performance was recorded where $0.5 \%$ $\mathrm{KNO}_{3}$ solution was used compared to other concentrations. Thus, it could be concluded that amaranth seeds should be primed with $0.5 \% \mathrm{KNO}_{3}$ solution for faster and higher seed germination of the crop.

\section{References}

[1] Raemaekers, R. H. (2001). Crop Production in Ttropical Africa. DGIC Belgium pp. 403-407.

[2] Musa, M., Singh, A., and Lawal A. A. (2014). Influence of Priming Duration on the Performance of Amaranths (Amaranthus cruentus L.) in Sokoto Semiarid Zone of Nigeria. International Journal of Agronomy, 1-4

[3] McDonald, M. B. (1999). Seed deterioration: physiology, repair and assessment. Seed Science Technology, 27: 177-237.

[4] Bray, C. M., Davison, P. A., Ashraf, M. and Taylor, R. M. (1989). Biochemical changes during priming of leek seeds. Annals and Botany, 63: 185-193.

[5] Basra S. M. A, Afzal, I., Rashid R. A, and Hameed, A. (2005). Inducing salt tolerance in wheat by seed vigor enhancement techniques. Int. J. Biol. Biotech., 2: 173-179.
[6] Khan, A. A. (1992). Preplant physiological seed conditioning. Hort. Rev, 14: 131-181.

[7] McDonald, M. B. (2000). Seed priming, pp. 287-325. In M.. Black, and J.D. Bewley (eds). Seed Technology and its Biological Basis. Sheffield Academic press, Sheffield.

[8] Ahmed, A. K., Johnson, K. A, Burchett, M. D. and Kenny, B. J. (2006). The effects of heat, smoke, leaching, scarification, temperature and $\mathrm{NaCl}$ salinity on the germination of Solanum centrale (The Australian bush tomato). Seed science and Technology, 34: 33-45.

[9] Paul, S. R. and Choudhury, A. K. (1991). Effect of seed priming with potassium salt on growth and yield of wheat under rainfall condition. Ann. Agric Res., 12: 415-418.

[10] Moosavi, A Tavakkol, R. Afshari, F. and Aynehband, A. (2009). Effects of priming on germination characteristics of four amaranth cultivars www.world.food.net. 16/1082010.

[11] Ojanuga, A. G. (2004). Agro ecological Zones of Nigerian MAPS. National Special Programme on Food Security, FAOUNESCO.

[12] Szabolcs, I. (1994). Prospects of soil salinity for the $21^{\text {st }}$ century. $15^{\text {th }}$ International Congress of Soil Science, Acapulco, Mexico, pp. 514.

[13] Sivritepe, N., Sivritepe, H. O. and Eris, A. (2003). The effect of $\mathrm{NaCl}$ priming on Salt tolerance in melon seedlings grown under saline conditions. Scientia Horticulturae, 97: 229-237.

[14] Jie, L. L, Ong S, Dong M. O., Fang, L. and Hua E. W. (2002). Effect of PEG on germination and active oxygen metabolism in wild rye (Lymus chinesis) Seed. Acta Prata Cult. Sinica, 11: 59-64.

[15] Chen, K and Arora, R. (2010). Dynamics of the antioxidant system during seed osmopriming, Post-priming germination, and seedling establishment in spinach (Spinacia oleracea). Plant Sci., 180: 212-220.

[16] Singh, A., Dahiru, R., Musa, M. and Haliru, B. S. (2014). Effect of Osmopriming Duration on Germination, Emergence, and Early Growth of Cowpea (Vigna unguiculata (L.) Walp.) in the Sudan Savanna of Nigeria. International Journal of Agronomy, 1-4. 